\title{
Human Life in the War on Terrorism: a Response to "the Risk Dilemma" by Michael Walzer
}

\author{
Asa Kasher ${ }^{1,2}$ - Amos Yadlin ${ }^{3}$
}

Received: 22 October 2015 / Accepted: 22 April 2016/

Published online: 29 July 2016

(C) Springer Science+Business Media Dordrecht 2016

Michael Walzer's "The Question of Risk"1 is a brief but important essay, presenting critical questions about the war on terrorism and answering them on grounds of his general conception. Some of Walzer's statements relate directly to previous essays of our own in which we proposed an ethical doctrine in the context of fighting terrorism. ${ }^{2}$ We are going to respond to Walzer's claims about the issues under consideration and use this opportunity to clarify some parts of our doctrine.

In our previous essays, we discussed the central issue to which fighting terrorism gives rise, namely terrorists operating from within a population not directly involved in terrorist activity. Walzer confers primacy on this issue, calling it "the core issue... How much risk must our soldiers take to reduce the risks they impose on civilians when they respond to attacks [from the midst of... civilian population]?". 3

\footnotetext{
${ }^{1}$ Michael Walzer, "The Question of Risk", in this issue.

${ }^{2}$ Asa Kasher and Amos Yadlin, "Military Ethics of Fighting Terror: An Israeli Perspective", Journal of Military Ethics 4:1 (2005) 3-32; "Military Ethics of Fighting Terror: Principles", Philosophia 34:1 (2006) 7584; Asa Kasher, "Operation Cast Lead and Just War Theory”, Azure Online (2009) 43-75. Some of Walzer's statements about our doctrine constitute a disagreement worthy of further discussion. It is carried out in the present exchange. Some of his statements, however, are groundless claims about our doctrine which we won't presently discuss; see footnote 24 below.

We take the meaning of "soldier" in Walzer's statement to be a person, usually a combatant, in military uniform and not necessarily one that serves in the Army rather than any other branch of the military forces. This is the way the term will be used in the sequel as well.
}

${ }^{3}$ Walzer, footnote 1 above, p. 289.

\section{Asa Kasher}

asakasher@hotmail.com

Amos Yadlin

amos@inss.org.il

1 Department of Philosophy, Tel Aviv University, Tel-Aviv, Israel

2 Shalem Academic Center, Jerusalem, Israel

3 Institute of National Security Studies, Tel Aviv University, Tel-Aviv, Israel 
Before contrasting Walzer's answer to our own, we must comment on some aspects of the formulation with which Walzer chose to present the question.

Our first comment refers to the fact that Walzer views the question as relevant to both the United States, "regarding the rules of engagement in Afghanistan," and Israel, in the context of Operation Cast Lead. ${ }^{4}$ There is undoubtedly a certain resemblance between the United States war in Afghanistan in recent years and Israel's fighting in Gaza in operations such as Cast Lead and Pillar of Defense. In both contexts, military combatants confront people fighting from within a civilian population that is not actively engaged in combat. In both contexts, there is a need for an ethical doctrine that takes into account both risk to the combatants and risk to the civilians living in the battlefield. Nonetheless, the differences between fighting in Afghanistan and fighting in Gaza are far greater and important than any similarities, requiring a separate discussion of each of the two contexts.

The first and quite obvious difference is that, while the fighting in Gaza is directly aimed at defending the lives of the citizens and residents of Israel and the state itself, the current fighting by U.S. forces in Afghanistan has nothing to do with direct - and probably not even indirect - defense of the lives of U.S. citizens and residents of the U.S. per se.

Moreover, the fighting in Afghanistan, which began after 9/11, started as a war between two states but quickly developed into a different type of conflict: the Afghan government fighting an internal battle against rebels who use guerrilla and terrorist tactics with the help of external - U.S. and other - forces. In that context, U.S. and its allies forces in Afghanistan were supposed to protect the Afghan civilians and their government against the rebels. Any harm wrought by soldiers to Afghan civilians, i.e., those not directly involved in the insurgency, was harm to civilians to whose benefit the Afghan nation, the Afghan government and the friendly forces working with it were supposed to act in the processes of reconstruction of state institutions and forces and of peacekeeping in areas of peace. ${ }^{5}$

By contrast, Israel's military activity in the Gaza Strip has a completely different strategic structure. The IDF does not fight in Gaza to help the Gaza government overcome rebels from within its population. In Gaza, the Hamas government deploys terrorists. Consequently, the IDF does not fight in Gaza in order to defeat the terrorists and ensure the wellbeing of civilians who are not directly involved in terrorist activity so that, at the end of the day, they can support a government that supports them. The IDF fights in the Gaza Strip in order to defend the citizens and residents of Israel against terrorists and weaken terrorist organizations to the extent possible. It does not fight in Gaza in order to ensure the wellbeing of civilians who are not directly involved in terrorist activity, but it does make an effort to reduce harm to them in the course of fighting terrorism. The IDF is not directly interested in the wellbeing of the civilians who are not directly involved in terrorist activity and does not desire to enhance their support for their government. It merely tries to reduce harm to them, because that is the IDF's ethical, moral and legal obligation.

It is important to stress another difference between the situation of the U.S. and allies forces in Afghanistan and that of the IDF in the Gaza Strip. The government of

\footnotetext{
${ }^{4}$ Ibid.

${ }^{5}$ Gen. Stanley McChrystal, the Commander of U.S. and Allied Forced in Afghanistan, defined the task of fighting in this spirit, using the now oft-cited phrase, "Defeat the Taliban, secure the population." See the recent publication, Stanley McChrystal, My Share of the Task: A Memoir (2013). An important historical question with clear relation to the ethical questions here under discussion is: what was the force operation doctrine between the end of the war in Afghanistan during the reign of the Taliban and the declaration of McChrystal's doctrine?
} 
Afghanistan, to the extent that it has the support of the forces of the United States and its allies, has effective control ${ }^{6}$ of some of the areas in Afghanistan where the warfare against the insurgents is taking place. By contrast, Israel has no effective control of the Gaza Strip, not even when the IDF activates large-scale operations there. Without effective control of Gaza, Israel does not bear moral responsibility for the routine of life there in which terrorists operate from within civilian populations not directly involved in terrorist activity.

The differences between the Afghan arena and the Gazan arena in terms of the relations between the four major factors - the military force, the local government, those fighting against the military force, and the population not directly involved in the fighting - justify a separate discussion of the context of each of these arenas. It would be pointless to import principles from Afghanistan to use in guiding the IDF in its activity in Gaza without undertaking an exacting examination of the justification for such an import from one context to another very different one.

Our second comment on the Walzer's presentation of the question refers to the description of the state of warfare under ethical and moral assessment. According to Walzer, under consideration is a situation in which there are risks at which our soldiers place civilians when they respond to attacks by terrorists. This is a problematic description of the situation, first and foremost because of what it is missing. The description of our soldiers as those who "respond to attacks" by terrorists is missing an essential part of any description of military activity, one of obvious moral importance. The fact of the matter is that our soldiers do not "respond" to anything but are rather engaged in defending the citizens and residents of Israel and the state itself against those terrorist attacks. The soldiers' actions are not retaliatory or punitive acts, whose ethical and moral status differs from that of defensive actions. It is important to note that the soldiers' actions are meant to provide immediate protection to anyone who has been harmed or is liable to be harmed from the terrorists' continued activity. A response could also be an act of deterrence whose status differs from a military action designed to provide immediate protection. ${ }^{7}$ In our opinion, the overall considerations of the risk of collateral damage depend on the objective of the military action (i.e., is it an action of immediate defense or rather an action meant for deterrence), and there is no reason to blur the distinction.

Furthermore, the description of the risk of collateral damage to the terrorists' neighbors - in the context of a defensive action taken against terrorist acts - as a risk at which our soldiers place civilians is misleading and bound to lead to unjustifiable ethical and moral conclusions. Such a description places the blame for harm to civilians on the soldiers as if they were the ones who created the risk. Nothing in this formulation expresses a central aspect of the situation: the terrorists attack Israeli targets while pretending to be innocent civilians, not wearing uniforms, not carrying arms in the open, and acting in close proximity to their neighbors - civilians of similar appearance who are not directly involved in terrorist activity - with the intention of creating a state of risk to those civilians via the soldiers' defensive actions. The responsibility for harm to those civilians must be placed, first and foremost, on those who created the situation

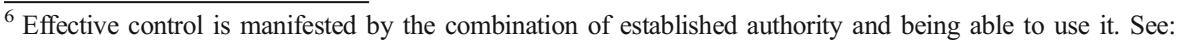
Yoram Dinstein, The International Law of Belligerent Occupation (2009), pp. 42-45. Walzer ignores the possibility that there would be a struggle between a state with effective control and a hostile force operating in the same area and trying to exert its will there. Effective control is determined by the ability to impose will, even through battle, rather than by full success in its imposition.

7 "The Principle of Operational Deterrence", see Kasher and Yadlin, footnote 2 above, p. 418.
} 
of risk, i.e., the terrorists. This responsibility must be taken into account when we examine the proper conduct of soldiers in such situations. ${ }^{8}$

Our last comment on the question in Walzer's formulation: we certainly accept the assumption, presupposed by the question, with respect to the efforts that should be made to reduce the risks to the lives of civilians who are in proximity to the terrorists but not directly involved in terrorist action. Still, recognizing the obligation to protect the human dignity of every person qua person, we view the efforts presupposed by the question as formulated by Walzer as only one of the many kinds of effort that must be considered in the context of moral deliberations. The overall picture of these efforts must also include efforts intended to reduce the risk to soldiers' lives when they are defending the citizens and residents of Israel and the state itself against terrorists' attacks.

Thus, the question we would like to discuss and respond to is this: what is the measure of risk our soldiers must assume in their efforts to reduce the risk of harm to civilian life - including the lives of civilians in the proximity of terrorists and who are not directly involved in terrorist activity as well as the lives of the soldiers themselves at a time when they are defending the lives of the citizens and residents of Israel and Israel itself against the attacks of terrorists?

Before we delve into the heart of the matter, we should briefly clarify the nature of the considerations that should be included in the discussion about the proper answer to the question before us. First, we believe that the discussion should be free of most considerations of "international public opinion." The media make much use of this vague notion, probably because they are using it to bolster themselves, as the media are the very arena in which different opinions are voiced and thus reach the ears of the public at large. A nation may certainly take an interest in how it is being portrayed in the international media - a portrayal valid with reference to a small group of people who happen to have the opportunity to voice their opinions in the public sphere - but, at the same time, it is unwise for a nation to attach too much importance to considerations related to its status in the international media when there are real questions of human life at stake - the lives of civilians, residents and the soldiers of the nation itself.

Similarly, it is inappropriate for a nation to confer too much importance on political considerations that lie in the realm of the nation's international relations, especially with friendly nations, when the nation's self-defense - including the defense of its citizens, residents and soldiers - is at stake. No responsible nation would completely ignore political considerations as such, as they may have a direct effect on key issues of national security, including questions pertaining to the defense of the state, its citizens, residents and soldiers. But even when immediate international relations have importance of the highest degree in a nation's self-defense considerations, it is doubtful that a state has the moral right to take steps liable to multiply losses among its soldiers and

\footnotetext{
${ }^{8}$ We should be precise in describing the significance of the differences we indicate between conflicts on different fronts. Our doctrine is meant to be universal in its principles and their moral posture. When the background assumptions (such as the assumption of effective control or the lack thereof) prevail, then the doctrine is supposed to apply to all situations, whether occurring in the Gaza Strip or in some province of Afghanistan. But in other situations, when the assumptions of the doctrine do not prevail, some other doctrine is supposed to apply, one that is based on other principles and requiring actions of different kinds. Our discussion of the differences leads to a conclusion that, in some of the United States and allies combat periods in Afghanistan, our doctrine applies, whereas in other combat periods it has not been fully applicable. Thus, the differences between Israel's conduct in the Gaza Strip and that of the United States in Afghanistan are not evidence of error either on the part of Israel or on the part of the United States.
} 
perhaps also among its civilians and residents at a later point only in order to comply with the immediate demands of friendly nations to avoid taking steps of self-defense, whether in general or specific steps. ${ }^{9}$

Many political and all media considerations in the debate about the morality of risking human life in the situations under discussion seem to us completely superfluous. By contrast, we believe that other concerns that should be considered are blatantly and unjustifiably missing from the debate. This is true of Walzer's current essay as well as almost all ethical and moral literature and legal writings. ${ }^{10}$

The discussions of the question before us and many other questions are conducted in a way that places obligations on the soldiers of the state in the name of international law or the doctrine of just war. We believe that this is a fundamentally distorted view of any soldier's values and norms. Every soldier in a civilized nation is also a citizen of the state in whose army s/he serves and acts on its behalf and carries out missions on behalf of the good of the nation as a whole. Because the soldier is also a citizen, the relationship between him/her and the state - in which s/he is both a soldier and a citizen - is complex and bidirectional: on the one hand, according to the oath of allegiance of Israeli soldiers, the soldier has duties to the state, its constitution and sanctioned authorities; on the other hand, the state has duties to the soldier, both because the soldier is a citizen and because $s /$ he has a special status as a citizen in military uniform.

The highest duty of a democratic state toward its citizens is to protect their lives, wellbeing and way of life. When a citizen goes into a military force, the nation's duty to protect his or her life is not abrogated, but takes on a unique form of a duty within certain important limitations. These limitations allow the state to send its soldiers on dangerous missions liable to significantly jeopardize their lives. Nonetheless, the basic duty remains: the state must have overwhelming reasons to assume the right to send its soldiers on such missions. When a soldier asks "what justifies the risk to which the state is exposing me in the mission on which it is sending me?" the state must have a justifiable and compelling answer. ${ }^{11}$

In ethical and moral debates about the risk to human life, we must take into account considerations affecting the state's answer to the soldier's question. Some parts of the state's answer can be presented in terms of basic values, such as the state's duty to defend its citizens, residents and itself; another part can be presented in legal terms, such as the basic laws of conscription and military reserve duty. The whole of the state's answer must conform to the constitutional demand for proportionality: the decision to

\footnotetext{
${ }^{9}$ A clear example from the Israeli context, one that has never been properly discusses from the moral perspective, is that conduct of the government of Israel in the days leading up to the Yom Kippur War.

${ }^{10}$ A notable exception is an essay by (Israeli) jurist Gabriella Blum. See: "The Dispensable Lives of Soldiers," 2(1) Journal of Legal Analysis 115 (2010).

${ }^{11}$ See: Asa Kasher, "The Principle of Distinction," 6(2) Journal of Military Ethics 152 (2007). Walzer (and others) claim that in answer to the soldier's question about the justification for risking his/her life one can respond with the moral importance of protecting human beings who are not attacking human beings who are not involved in fighting. This is a weak argument and ignores the soldier's own moral and ethical stance as the soldier, too, is a human being who is not attacking people who are not involved in the fighting. The question par excellence in this context is why Walzer considers the soldier's life to be worth less than the life of the terrorist's neighbor who, for reasons of his/her own, from intentional hosting of the terrorist to concern for his/ her own property, chooses not to evacuate. Walzer fails to answer this question directly or persuasively.
} 
risk human life must be undertaken only in order to achieve a necessary goal of protecting human life ${ }^{12}$ to the extent necessarily required to do so.

Moreover, considerations of international law will appear in these discussions as considerations embedded in the obligation that Israeli law imposes on Israeli soldiers to behave according to certain principles of international law. Israeli soldiers are not bound by international law or the doctrine of just war at its core, but rather by the extent to which the state imposes the obligation to act according to them, whether by virtue of law or by virtue of military ethics. ${ }^{13}$

The prevalent trend of ignoring the relationship between the civilian in military uniform and the state leads to some unacceptable results. For example, let us imagine two nations at war with their enemies. Nation A is a democracy where a soldier always has the right to question the state's right to risk his/her life and where a decisive answer is usually provided; nation $\mathrm{B}$ is totalitarian where the soldier never has the right to ask the question and where soldiers are used as cannon fodder. Let us assume that, despite this difference, both nations fight their enemies the same way from the perspective of international law: both use only permissible weapons, aim only at military targets, respect the principles of distinction and the principle of proportionality, treat POWs appropriately, and so on. Focusing on the external context of fighting the enemy according to international law would lead us to conclude that, in terms of warfare, there is no significant ethical or moral difference between nation $\mathrm{A}$ and nation $\mathrm{B}$. This conclusion is patently absurd. Nation A respects the human dignity of the citizen in uniform whereas nation $\mathrm{B}$ harms the soldier time and again and without compunction. The ethical and moral difference between them is vast. Any approach that ignores this difference requires a radical rethinking.

As to the considerations of the internal context, that of the relationship between the state and its citizens in military uniform, they are uniquely important in Israel's situation because all soldiers who are neither officers nor NCOs, as well as many junior officers are conscripts, serving in the IDF as part of their mandatory military service. In addition, soldiers and officers also serve in the IDF in the context of reserve duty. ${ }^{14}$ A democracy may draft citizens into the military by virtue of law and send many of them into war, thus exposing them to significant risk, only for vital reasons. The general spirit of such reasons is one of a "last resort" decision, made for want of a better alternative. We believe that a moral and ethical assessment of going to war must use the

\footnotetext{
12 The constitutional formula of proportionality uses the expression "proper purpose," but when human life is at stake, a purpose can be proper only if it is necessary in order to protect human life, in the larger sense that also includes the state's self-defense.

${ }^{13}$ See Asa Kasher and Amos Yadlin, "Defining Norms for Warfare in New Situations: Between Military Ethics and the Laws of War," Military and Strategic Affairs Vol. 5, No. 1, May 2013, http://www.inss.org.il/ uploadImages/systemFiles/MASA5-1Eng4_Kasher\%20and\%20Yadlin.pdf.

${ }^{14}$ In Israel, one sometimes hears the assertion that many combatants in the IDF are volunteers even though they have been drafted into the IDF as part of the state's mandatory military service, because they are serving in units in which the IDF places only soldiers who want to serve in them, such as air teams, commandos and some of the regular brigades (see, e.g., Amos Harel, Let Every Hebrew Mother know: Some Aspects of the Modern IDF (Hebrew), Tel Aviv: Kinneret, Zmora-Bitan, Dvir Publishers Ltd., 2013, chapter 2, p. 42). This assertion is based on a conceptual error: a soldier serving in the paratroopers brigade, for example, did indeed express an interest in serving in it, but did so at a juncture not in which s/he was given the option of serving in the paratroopers brigade or not serving at all, but rather at a juncture in which s/he was asked to choose between serving in the paratroopers brigade or in some other unit. That which is called "voluntary service" in the paratroopers brigade is not, in fact, true voluntary service but rather an expression of preference within the options of mandatory service.
} 
"last resort" principle both with regard to the external context of relations between the state and other states and forces and with regard to the internal context of the relations between the state and its citizens in military uniform. In the external context, the state makes use of the principle of last resort and in the internal context it is appropriate for the state to make use of the principle of self-defense ${ }^{15}$ allowing risk to soldiers' lives if there is no choice when self-defense is at stake. The prevalent trend of ignoring the ethical and moral obligation to include also the considerations of the internal context in the discussion is, in our opinion, amazing and unjustifiable. ${ }^{16}$

Possibly, ignoring considerations of the internal context is regarded justified and even natural by those who thinks of citizens in military uniform as a force of volunteers. According to this line of reasoning, those who volunteer to serve in a military force in combat positions accept, by virtue of such volunteering, an arrangement in which the state may send them on dangerous missions as it sees fit. This line of argument seem to us to be erroneous. Even if we assume that the state's obligation to its citizens in military uniform in the context of a volunteer military force is weaker than its obligation to its citizens in military uniform doing their mandatory military or reserve service, the moral question remains: is a democracy allowed to risk the life of its own citizens in military uniform even when there is a better alternative for defending human life either directly or indirectly? The fact that volunteering was involved does not provide moral justification for any and every arrangement of using volunteers, the same way that there is no moral justification for allowing arrangements of slavery were there are people who would volunteer to act as slaves to others.

Walzer mentions the situation in which people volunteer to place themselves in danger. He recounts speaking with both U.S. and Israeli soldiers who believe that taking risks in order to minimize the number of civilian casualties is critical for the pride they feel in fulfilling their duty. ${ }^{17}$ Indeed, the IDF legacy is replete with incidents in which fighters volunteered to risk their lives under such circumstances and some were killed in the course of doing so. But the tendency to praise such fighters for volunteering to assume risk does not reflect a real starting point for a discussion of the above-formulated soldier's question when the soldier has not volunteered to risk his/her life under such circumstances and who asks the commanders, the military force and the state for their justification when they order him/her to risk his/her life under such circumstances. Praise for action performed beyond the call of duty cannot serve as the basis for defining the call of duty. An act that arouses pride in some soldiers is not necessarily incumbent on all other soldiers in similar situations.

In that same testimony about his conversations with soldiers, Walzer says that some believe that assuming personal risk under such circumstances is "part of their job." We, too, have heard similar assertions, but we have never been impressed by them. First, how do we know that assuming such risks is indeed part of the soldier's duty in the

\footnotetext{
${ }^{15}$ Yadlin and Kasher, footnote 2 above, p. 394.

${ }^{16}$ Walzer attributes importance to the fact that in Israel "the soldiers are everybody's children, which isn't true, these days, of the US" (Walzer, footnote 1 above, p. 290). The sense prevalent in Israel that we are talking about "all our children" may explain Israel's particular concern for keeping its soldiers safe, but that is irrelevant in the current debate in which ethical and moral consideration remain the crux of the matter.

${ }^{17}$ Ibid, p. 289-293. It may not be superfluous to point out that there is no justification to risk a soldier's life for the purpose of strengthening pride in one's duty. As professional commanders know, there are many non-risky ways of enhancing unit pride and pride in one's duty.
} 
circumstances under discussion? Secondly, and not less important, even if it is, in fact, part of his/her duty, does the definition of military duty in a way that leads to the assumption of such risks meet ethical and moral tests? In other words, it may be that the definition of duty is imaginary, a type of prejudice prevalent among soldiers, and it may be that the definition of duty is real but does not meet the proper tests. The conduct of the combatant military police company and the conduct of the CIA investigators at Abu Ghraib in Iraq are well-known examples of both possibilities.

We shall now consider Walzer's proposals for principles that are supposed to guide soldiers in the circumstances under discussion. Here is what Walzer says: "We want soldiers to minimize [the number of civilian deaths], as best they can, even at some risk to themselves. But the risk-taking can't undermine or endanger the mission."18

We have already demonstrated that the situation of the current military activity by the U.S. military presence in Afghanistan against the insurgents is unlike the military activity by the IDF against the terrorists in the Gaza Strip. Let us assume that the principle Walzer proposes should be applied, as is, to IDF soldiers during military activity in Gaza of the kind represented by Operation Cast Lead or Operation Pillar of Defense.

The principle Walzer proposes tugs in two opposite directions and we have no choice but to select one or the other. On the one hand, the principle demands that soldiers ought to minimize [the number of civilian deaths], as best they can" while on the other hand it demands that they act "even at the cost of assuming some risk to themselves." If the soldiers are supposed to make efforts "the best they can", then they must be prepared to assume great risk as well. As we know and acknowledge, trying one's best (or, to use the language of the IDF's ethical code, "persevering") is supposed to typify the conduct of soldiers even in regular engagement with an enemy force in which, by the nature of the activity, they are prepared to assume great risks, and when necessary even take extreme risk, on the verge of self-sacrificing their lives. At first glance, the first part of the proposed principle demands that soldiers do something "at their best", i.e., up to the point of extremely risking their lives. On the other hand, Walzer's rule demands that soldiers do so at cost of assuming "some risk to themselves," i.e., only at the cost of a moderate risk, one that certainly does not reach the level of great risk or an extreme risk to one's life. The conspicuous inconsistency between the two parts of the proposed principle leads to the conclusion that the formulation "at their best" is merely a turn of phrase rather than a guideline as to the level of risk required in the context of the effort to minimize collateral damage. Let us assume, therefore, that Walzer's principle requires readiness to reach the level of "some risk" and that, within the narrow limits of this setting, soldiers should make as great an effort as possible as long as they do not undermine or endanger the possibility of carrying out the mission. ${ }^{19}$

\footnotetext{
${ }_{18}$ Ibid. The guideline formulated as "some risk" did not appear in the response of Walzer (with Avishai Margalit) to our doctrine (see Asa Kasher and Amos Yadlin, "Assassination and Preventive Killing," 25 SAIS Review 41 (2005); Avishai Margalit and Michael Walzer, "This is not the way to conduct a just war," Haaretz opinion, April 8, 2009, www.haaretz.co.il/opinions/1.1254834; Avishai Margalit and Michael Walzer, "Israel: Civilians and Combatants," 56(8), The New York Review of Books, May 14, 2009, www.nybooks.com/articles/ archives/2009/may/14/israel-civilians-combatants). The current version is closer to our position more than the version in that response.

${ }^{19}$ Below, we shall return to the assertion that the effort to minimize collateral damage must not be made at the cost of undermining the accomplishment of the military mission at stake.
} 
A key phrase in the principle Walzer proposes is "some risk." Our view is that this phrase can serve a certain type of soldier in a certain type of situation but cannot form the basis for an ethical, justifiable and practical principle of guiding soldiers in the situations here under consideration.

In a volunteer army, ${ }^{20}$ a commander may allow his soldiers, if there aren't many, to place themselves at "some risk" i.e., a moderate risk, in order to reduce collateral damage, to the extent they see fit, without undermining the accomplishment of the mission. Each soldier will have to make the personal decision as to what constitutes "some risk" s/he is willing to assume under the given circumstances. Nonetheless, $\mathrm{s} / \mathrm{he}$ would have to take into consideration that every one of his/her comrades, commanders and subordinates would also have to determine what constituted "some risk" for him/ her. The coordination needed for military operations, which rests on the uniformity of commands, rules of engagement, procedures, doctrines and the law would not be a matter of course and fall into place on its own; it would become necessary to coordinate a range of definitions of what constitutes "some risk." We are willing to assume that in a small volunteer military unit a commander could at times manage this complication without disrupting the accomplishment of missions.

However, in the conditions prevailing in fighting terrorists in the Gaza Strip and similar arenas we are not talking about a small volunteer military unit. Under the conditions prevailing in Gaza and elsewhere, we are talking about very many combatants and coordination among them is critical for carrying out the missions. The commander cannot allow every soldier to decide his/her own level of "some risk" without damaging the effort of accomplishing the mission. The commander must decide what constitutes "some risk" that the soldiers will have to assume in order to diminish collateral damage. It is unreasonable that different regiment or brigade commanders each would decide what constitutes "some risk" in which to place their soldiers. As we emphasized above, soldiers have the right to expect the state's answer - to be provided via their commanders - to the question of why they are being sent on any military mission carrying any level of danger. It is ludicrous to think that the state's answer be phrased in terms of the variable personal "values taste" of commanders when it comes to what they consider "some risk" to be. There must be some principle the contents of which does not reflect personal taste but rather an orderly ethical decision based on considerations of values, ethics and morality that is binding on all soldiers in a given set of circumstances. Every case would still present personal differences of judgment, but these would be the result of professional considerations rather than a pluralism of values among commanders. The state's response to the soldier's question must be clear and precise rather than elusive or fuzzy. The "some risk" principle does not meet the fundamental demands of the military ethical arrangements in a democratic state.

It is possible to instruct soldiers on their conduct by using clear principles and rules, but it is also possible to contribute to soldier instruction by presenting priorities meant to help their decision making in particular sets of circumstances. Walzer presents priorities he believes are "morally required for the obvious reasons." Under discussion is the situation in which one can either risk the lives of soldiers, on the one hand, or risk the lives of civilians who are not directly involved in terrorist activity, on the other hand. In such a situation, claims Walzer, it is preferable to risk the lives of soldiers because the civilians are, all of them or most of them, innocent people, unarmed and

\footnotetext{
${ }^{20}$ In the full and precise meaning of the phrase. See footnote 14 above.
} 
frighteningly vulnerable, and the soldiers are armed and trained to fight and to protect themselves and each other." 21 At first glance, Walzer's assertion seems natural and reasonable, but at second glance one realizes that it doesn't hold water. Were we discussing a joust in which a trained and confident knight was facing a terrified, empty-handed peasant who had never jousted in his life, we would admit that the fight was unfair. But the situations under discussion are nothing like that. ${ }^{22}$ These situation involve fighting in which there is risk to people of different status and the moral question is whether there is any moral justification for risking members of one group in order to reduce harm to members of another group?

We do not accept the assumption that in a combat situation in which infantry, armor or other ground military force units are battling terrorists so as to protect the nation's citizens and residents and the nation itself, the risk to the soldiers' lives is always less than the risk to the lives of the people who are the terrorists' neighbors and are not directly involved in terrorist activity. Here are some of the dangers to which soldiers are exposed and from which the terrorists' neighbors are exempt:

- Soldiers are usually the target of enemy, terrorist fire, whereas the civilian neighbors of the terrorist are usually not the target of the soldiers' fire.

- Soldiers are exposed to dangers posed by mines, IEDs, fougasses, offensive tunnels, abduction tunnels and more, whereas the civilians hiding in their basements during the fighting are not exposed to these or similar dangers.

- The soldiers' weapons are usually insufficient in providing full protection against danger as long as they are fighting, whereas civilians can usually achieve full protection against fire if they respond to warnings and leave their homes for a short period of time or take cover at home.

Here we should return to the reservation according to which one must not allow the effort to reduce collateral damage, while assuming "some risk" to the soldiers' lives, in Walzer's formulation, to undermine the possibility of the soldiers to accomplish their mission. Were it not for the fact that the mission met the demand of proportionality, both Walzer and we would oppose its fulfillment, and we presume that Walzer would not be satisfied with the demand of "some risk" to the soldiers' lives in order to reduce collateral damage but would demand not to cause any collateral damage because the mission was not proportional. Let us therefore assume that the mission is proportional. In such a situation, assuming "some risk" to soldiers' lives would take the form of taking prior action designed to separate terrorists from their neighbors before carrying out the required engagement with the terrorists. Obviously, such prior action would affect the possibility of the soldiers to accomplish their mission because it would eliminate the element of surprise, reveal the soldiers' positions, and so on. If "some risk" taking should not affect the possibility of accomplishing the mission, we must

\footnotetext{
${ }^{21}$ Walzer, ibid., footnote 1 , p. $289-293$. This description contains factually problematic aspects, which we shall set aside for the moment.

${ }^{22}$ Discussions about asymmetrical warfare often include assertions about the increased obligations that must be imposed on the stronger party and the discounts that must be given to the weaker one, as if the discussion was about a joust between knights whose fairness must be ensured. But the kind of asymmetrical conflict with which we are dealing, unlike jousting, involves terrorists attacking the citizens and residents of the state and the state itself.
} 
conclude that "some risk" taking should not be assumed, because it interferes with the possibility of the soldiers of successfully carrying out their mission.

Therefore, we do not believe there is any moral validity to Walzer's priorities, which are based on an unrealistic view in which battling terrorists is akin to jousting or based on a mistaken comparison between the risks to which soldiers are exposed and the risks to which terrorists' neighbors are exposed.

The soldier's question then remains unanswered: what justification does a nation have for exposing him/her to risk in order to reduce collateral damage in fighting in an area that is not under the effective control of the state? Here we need to further clarify the soldier's question given the assessment of risks to which soldiers are exposed when fighting terrorists, part of which we have just presented. The state's obligation to fight terrorists in order to protect its citizens, residents and self is intimately bound to the authority the nation has to send its soldiers to operate in dangerous situations. ${ }^{23}$ But there is a difference between the risk soldiers experience as they together battle terrorists and "some risk" they experience because of an effort to reduce collateral damage. While the former is natural, necessary and justified, the latter is additional and requires special justification. The soldier's question is therefore: what justification does the nation have for exposing him/ her to risk not only in order to carry his/her duty in fighting the enemy but also in addition as much as required to reduce collateral damage? We believe that the soldier's question remains unanswered in any justified and compelling way.

Walzer and others present a choice between "zero risk" and "some risk," and attribute the former to us while opting for the latter themselves. To this we have a twofold answer: there is no foundation to attributing the former option to us, and presenting the choice between these two options is problematic.

The assertions attributing to us a "zero risk" principle stem either from total misunderstanding or from complete fabrication. Soldiers in ground military activity operate against terrorists under conditions in which there are unavoidable dangers. As part of the dangerous military activity it is obvious that soldiers try to carry out the mission of defeating the terrorists while protecting their own lives ("force protection") as much as possible, while also paying as much attention as possible to reducing collateral damage without allowing this to affect either the accomplishment of the mission or the lives of the soldiers. In a situation in which the soldiers' lives are already at risk, the soldiers must consider reducing collateral damage as long as they do not jeopardize the mission and protect their own lives. It is further worth noting that considerations of proportionality include in the military advantage gained by a certain military action the reduction of risk to soldiers' lives. Walzer and others making similar claims do not express any awareness of this aspect of proportionality considerations.

As for the second part of our answer, in ground military activity of the sort here under discussion, the choice between "zero risk" and "some risk" is illusory. As we have seen, no such situation carries "zero risk" while "some risk" is not sufficiently defined. The real choice is between "justified risk" and "excessive risk." In many cases, the risk that Walzer and others are interested in constitutes "excessive risk." The risk to soldiers in sorting the terrorists out from among the neighbors in the terrorists'

\footnotetext{
${ }^{23}$ From time to time the argument is made that according to our doctrine soldiers cannot be exposed to "any danger." We have heard and seen the expression "zero risk" attributed to us. The assertions attributing this approach to us are absurd. We shall return to this point momentarily.
} 
vicinity in an area not under Israel's effective control, after the neighbors have already been thoroughly warned about the risk posed to their lives because of their proximity to the terrorists and most have already evacuated, is excessive.

It is important to note that the obligation to make an effort to reduce collateral damage is included in our doctrine ${ }^{24}$ and is consistently manifested in the reality of Israel's fighting, even if this does not entail an obligation of the part of a soldier to assume risk in order to reduce collateral damage beyond what is necessary to carry out the mission facing the terrorists. Here are three examples.

Example no. 1: Our doctrine contains a principle that requires the IDF to issue constant warnings in order to get civilians who are not directly involved in terrorist activity out of the terrorists' way. ${ }^{25}$ In Operation Cast Lead, Israel operated an array of warnings of unprecedented proportions. $^{26}$ There is no doubt that, as a result, the number of collateral casualties was significantly reduced.

Walzer notes that the U.S. experience in Vietnam teaches that "warnings are not effective or not effective enough," because some of those warned do not evacuate their homes for different reasons. ${ }^{27}$ One may assume that a similar phenomenon occurs in every place there is warfare of the type under discussion. Given such a phenomenon, the military force is supposed to operate on the basis of the demands arising from the proportionality principle. Moreover, our doctrine demands that even if the collateral damage expected from a particular military action meets the requirements of proportionality, the military force is still under the obligation to make an effort to reduce collateral damage, i.e., beyond what is required of it on the basis of the considerations of proportionality alone. ${ }^{28}$ A situation could arise in which a warning issued to civilians might foil any possibility of carrying out the military mission or severely compromise its measure or chances of success. Even in such a situation, the army must operate on the basis of the proportionality principle and also reduce the collateral damage beyond what is required of it on the basis of the considerations of proportionality alone. ${ }^{29}$

Example no. 2: During the planning of a targeted killing operation, a conspicuous and self-evident application is made of considerations of proportionality, but special efforts are also made to reduce collateral damage as much as possible, beyond what is required of it on the basis of the considerations of proportionality alone. The planning stage includes complex and sophisticated professional activity that makes use of tools

\footnotetext{
${ }^{24}$ Yadlin and Kasher, footnote 2 above, p. 408.

25 Ibid, p. 417.

${ }^{26}$ Walzer attributes to one of us the claim that in that operation "thousands of phone calls" were placed (Walzer, footnote 2 above, p. 6). This is an error that ought to be corrected. On various occasions, we noted the fact that during Operation Cast Lead, more than 150,000 telephone calls were made. See Kasher, footnote 2 above. In this context, see statements made by Col. Richard Kemp, a decorated senior British officer, Testimony at the UN: UK Commander Challenges Goldstone Report, UN WATCH (2009), www.unwatch. org/site/apps/nlnet/content2.aspx?c=bdKKISNqEmG\&b=1313923\&ct=7536409.

${ }^{27}$ Walzer, footnote 1 above, p. 289-293.

${ }^{28}$ Yadlin and Kasher, footnote 2 above, p. 411.

${ }^{29}$ Ibid, pp. 411, 417.
} 
borrowed from operations research to choose the method and means that will ensure the highest likelihood of killing a certain terrorist while reducing collateral damage as much as possible given the circumstances of a military action of the targeted killing type.

Walzer cites testimony of U.S. soldiers in Afghanistan according to which, in circumstances of uncertainty about the collateral damage anticipated, they decided "to avoid civilian casualties, and there would be other chances to get the bad guys on the roof." 30 We will again disregard the differences between the current context of U.S. forces fighting in Afghanistan and the current context of Israeli forces fighting in the Gaza Strip, and assume that the comparison is warranted. A decision to delay a targeted killing operation is hardly rare or unusual in this part of the world. Chief of Staff (now [former] Minister of Defense) Leut. Gen. Moshe Ya'alon ordered such a postponement in the attempts to carry out a targeted killing of the terrorist Salah Shehadeh. Delaying a targeted killing when it is possible to carry it out stems from the obligation to reduce as much as possible the collateral damage resulting from the action. However, it behooves us to be accurate and express our reservations about using Walzer's testimony, that "there would always be another opportunity" to take out the target, in an irresponsible way. At times, the claim may be true based on a given intelligence assessment, but sometimes the claim lacks any foundation in intelligence and may actually be false. In such cases, postponing the action would be undesirable and be justified only if taking immediate action were to fail to meet the requirements of proportionality.

Example no. 3: When a terrorist finds refuge in an area under the control of the Palestinian Authority, in a building where civilians are present who are not directly involved in terrorist activity, the military force can act in one of three ways: it can bomb or shell the building destroying it with all its occupants; it can send an infantry force to penetrate the building to try to evacuate the civilians before it harms the terrorist; or it can use a heavy armored vehicle, such as a specially outfitted tractor, to start collapsing the walls of the building so as to force the civilians to leave and the terrorist to surrender. All three options are open to the military force in the regular circumstances of Israel fighting against terrorists.

The first option does not expose the soldiers to risk and achieves the aim of foiling the terrorist's hostile activity, but involves significant collateral damage. Under certain circumstances, it may meet the proportionality requirements, but even so it will not be chosen if there is a better way of attaining the goal while causing less collateral damage. The second option places the soldiers at high risk and reduces the chances of achieving the objective only in order to reduce

\footnotetext{
$\overline{{ }^{30} \text { Walzer, footnote } 1 \text { above, p. } 290 .}$
} 
collateral damage. Therefore, according to our approach, it would be inappropriate to choose it. $^{31}$ In prevalent cases, proportionality considerations would also rule it out. ${ }^{32}$ The third option makes it possible to carry out the mission and avoid collateral damage. It does not place the soldiers operating the tractor at risk beyond the risk to which they are in any case exposed by virtue of their presence in a war zone for the purpose of carrying out other missions. Therefore, this is the choice that should be made: it is immeasurably better than the second option and obviates the first.

In each of the three examples above, the military actions include efforts to prevent collateral damage but do not place the soldiers at "some risk" whose only purpose is to reduce collateral damage.

Walzer maintains that it is not enough that soldiers not intend to inflict harm on civilians; they must intend not to harm them. We are fully in accord with this moral demand. But Walzer adds that the soldiers' intention not to harm civilians can be expressed only via the risk the soldiers assume themselves in order to reduce risks to the civilians. ${ }^{33}$ We do not share this belief. It is neither reasonable nor moral. The soldiers' intention not to harm civilians can be expressed in many ways as we have demonstrated, and the claim that it is the soldiers' duty to risk themselves to reduce the risk to civilians is baseless.

In conclusion, Walzer asserts that there is strong moral argument that soldiers should accept some risk in order to minimize the risks to civilians." ${ }^{34}$ We believe that what Walzer and others are expressing are mere prima facie considerations that fail to amount to "a strong moral argument." In our opinion, the soldier's question - what justification do his/her commanders, the IDF and state have in placing him/her in "some risk" merely to reduce collateral damage as much as possible - remains unanswered. And as long as it remains unanswered, it is appropriate not to place soldiers in "some risk" only in order to reduce collateral damage. Nonetheless, when carrying out a necessary and proportional mission, it is appropriate to use other ways such as issuing prior warnings, postponing the mission to a later date, using precise weapons, and so on - in order to reduce the collateral damage as much as possible without interfering with the proper accomplishment of the mission.

Acknowledgments A Hebrew version of the present exchange appeared in Law and Business 17 (2014) 671-685. We thank the editor, Dr. Eli Bukspan, and the publishers for permission to publish an English translation of the exchange in Philosophia.

\footnotetext{
${ }^{31}$ We do not know if Walzer would describe this as "some risk."

${ }^{32}$ Here is an example of ruling out the second option because of proportionality considerations: in a certain building in the Gaza Strip, terrorists are preparing an immediate missile launch at Sderot. Were an army company to be dispatched to the location, it would in all probability not get there before the missile was launched; also, were the company to engage the terrorists in battle to prevent another rocket launch, there would probably be casualties among the soldiers. So, on the one hand, we have the risk to the lives of some 20 Israeli citizens the missile could conceivably kill and the risk to the lives of 10 soldiers who could be killed in fighting the terrorists, and, on the other hand, the risk to the lives of a few of the terrorists' neighbors.

${ }^{33}$ Margalit and Walzer, footnote 18 above; Jeff McMahan, Foreword, in KiLlingby Remote Control: The Ethicsofan Unmanned Military ix (Bradley Jay Strawser ed., 2013).

${ }^{34}$ Walzer, footnote 1 above, p. 289-293.
} 